\title{
Traditional coppice in South East England: the importance of workforce engagement for development
}

\section{Debbie Bartlett}

\section{Introduction}

Historically coppicing was the most common way in which England's woodlands were managed to provide small diameter roundwood for building, furniture, household and farm utensils, and particularly fuel for heating and cooking. Local conditions influenced both the native trees and the demand for products, with selection of "desirable" species over time resulting in the composition of today's woodlands (Geraint Jenkins 1965, Edlin 1973, Rackham 1986). As coal became more readily available and wood was replaced by other

Faculty of Engineering and Science, University of Greenwich, Central Avenue, Chatham Maritime, Medway, Kent, ME4 4TB (UK)

@ Debbie Bartlett (d.bartlett@gre.ac.uk)

Received: Aug 12, 2015 - Accepted: Feb 08, 2016

Citation: Bartlett D (2016). Traditional coppice in South East England: the importance of workforce engagement for development. iForest 9: 577-582. - doi: 10.3832/ifor1809-009 [online 2014-04-04]

Communicated by: Tomas Vrska licy decisions is recommended.
This paper describes research into the historic importance of the coppice industry, now largely restricted to south east England and the relevance of this to current rural development policy. The economic and social contexts have altered significantly over time with product substitution and changing consumer aspirations, and particularly the availability of alternative fuel sources. Over the last fifty years the "value" attached to coppiced woodlands has shifted away from resource exploitation and towards a greater appreciation of them for wildlife, recreation, amenity and cultural heritage. This has increased wider public awareness of and appreciation for coppicing as a management technique and, consequently rising concern over the reduction in area managed. This was assumed to be due to market failure but attempts to reverse this by creating new outlets failed. The reason for this has been explored by engaging directly with the workforce, both individually and in focus groups. Coppice workers were found to be more numerous, active and enterprising than previously thought, and many were found to be working in family groups servicing traditional markets. They were unaware of concerns about decline in the area coppiced or initiatives to address it. Issues currently affecting their businesses included housing costs, rural crime, harvesting restrictions, loss of yards and training needs. It is concluded that Government policies to promote woodfuel are not likely to succeed without active engagement with the workforce to understand their perspectives and enabling them to participate in po-

\section{Keywords: Chestnut, Workforce, Development, Policy}

materials such as metal and plastic the range of products reduced. The two World Wars had a dramatic impact on woodland, and the Forestry Commission was set up in 1919 , as a response to the shortages experienced during the 1914-18 War, to ensure the long term timber resource. This resulted in many former coppices being overplanted with fast growing non-native conifers for future clear felling. Despite the need for periodic thinning this does not provide regular work for local people as many forestry contractors travel considerable distances, reflecting the investment in machinery and the distances between conifer plantations, particularly in Southern England. In contrast rotational coppicing, with a proportion of a wood harvested, processed and marketed each year, can provide sustained livelihoods for local workers. This was often - but by no means always - combined with seasonal farm work; reduction in this option with post 1945 intensification of agriculture undoubtedly affected the coppice industry.

In the 1980 s there was a paradigm shift in policy, reflecting the emerging environmental agenda. This resulted in the Forestry Commission switching from planting productive softwoods to encouraging native broadleaves, focusing on the "value" for woodland biodiversity and recreation and amenity (Forestry Commission 1985). This led to a resurgence of interest in coppicing, with various initiatives to encourage, for example woodland butterflies, by giving grants for coppice management (Warren et al. 2001).

The South East is the most wooded region in the UK (Forestry Commission 2004), with a high proportion of "ancient woodland" known to have existed prior to 1600 AD (Rackham 2003). The species com- 
position and management has varied over time but these woods have recorded history (Bannister 2007, Bannister et al. 2005) showing that until relatively recently they were busy places, particularly during winter. Research into the coppice industry was carried out by FitzRandolph \& Hay (1926), Edlin (1973), and more recently by Collins (2004). Chestnut (Castenea sativa) was a very important coppice species in the south east in the $18^{\text {th }}$ and $19^{\text {th }}$ centuries, providing poles for the lucrative hop industry, pit props for the coal mines, and was the main raw material for fencing. Despite this, a number of studies (Collins 2004 - for review see Bartlett 2011a) suggested that some hazel and mixed species coppicing was taking place, although far less that in former times, the chestnut sector appeared to be in terminal decline. This resulted in the idea of a "coppice problem" with significant public funding directed at finding new markets to "drive" management (Betts \& Claridge 1994), to support the non-market products (i.e., biodiversity, landscape and recreation). These were not successful (see Bartlett 2011a for a detailed review). The paradigm that woodlands in South East England were largely unmanaged was reflected in the publication of "A Woodfuel Strategy for England" (Forestry Commission 2006) promoting coppiced product as a renewable energy resource.

Despite the general assumption, firmly held by the Forestry Commission, Natural England and the local authorities in the South East in the early 2000s, that coppicing had virtually died out except on nature reserves, the author, in the role of Kent Woodland Officer, was aware that the chestnut fencing industry was vibrant and the Sussex and Surrey Coppice Group had

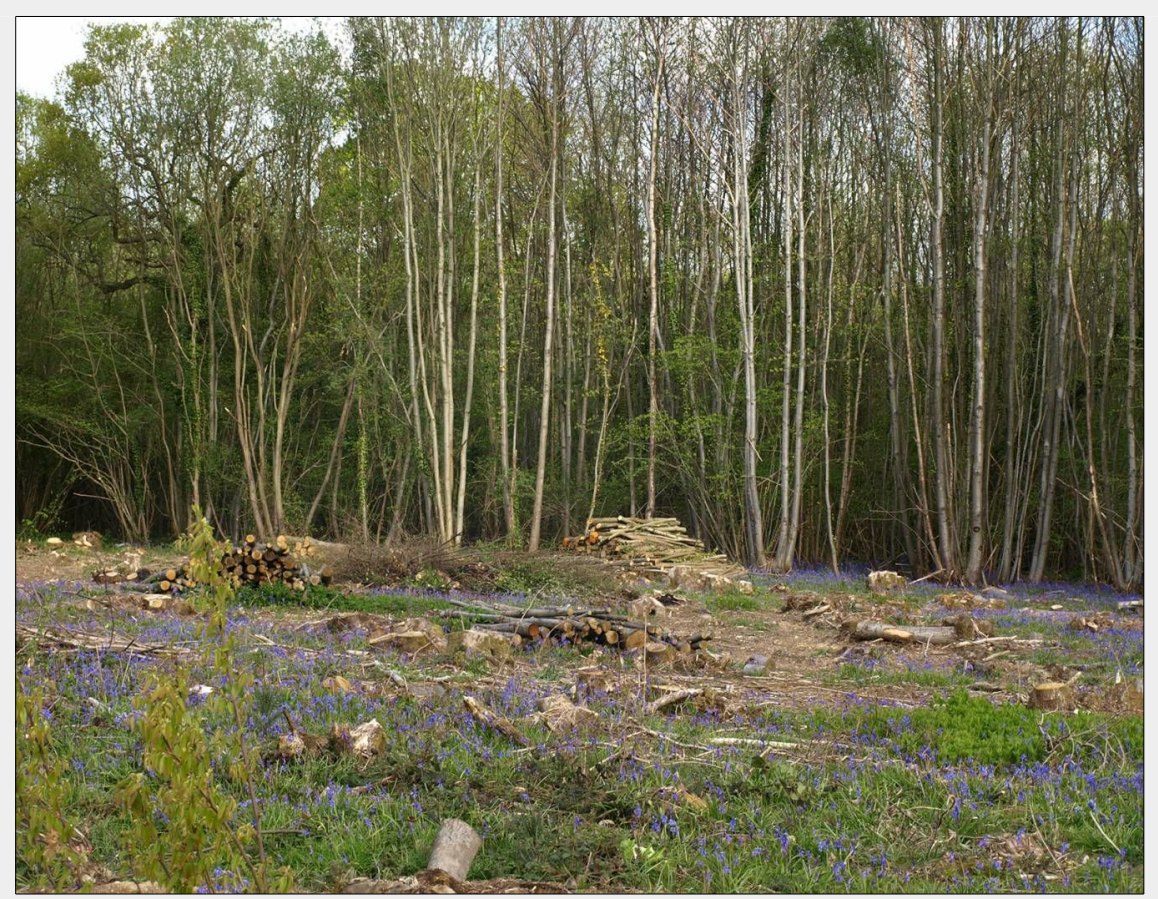

Fig. 1 - Twelve year old chestnut coppice. almost eighty members involved principally in coppicing hazel. This led to a long term investigation based direct engagement with the workforce to test the assumptions about the decline of the industry by determining how much coppicing was actually taking place and find out more about the workforce, with the specific aim of exploring whether there were any issues that were limiting coppice management. The rationale was that plans for the future are not likely to be achieved if the present situation is not adequately understood.

\section{Methods}

A mixed methods approach was taken involving:

- a survey of the area actively coppiced. This was implemented by directly asking the cutters the area they had cut, the tree species, and the location. This had the additional advantage of raising worker's awareness that "outsiders" consider their work important. Taking a "citizen science", rather than systematic survey, approach is increasingly accepted as justified when data is difficult to obtain by other means (Bonney et al. 2009, Silverton 2009). Accuracy verification was carried out by visiting and visually checking about $10 \%$ of returns. A significant problem in research into coppicing is that rotation times are variable, from 3 to $40+$ years, depending on species and end product. As an example, chestnut coppice that has not been harvested for fifty years might be considered as overstood, derelict or abandoned although to a coppice worker producing post and rail fencing it is almost ready for harvesting. Equally for a pale maker a sixteen year old stand maybe overstood; walking stick

interference. This placed on them; the Commission was certainly the last land owner to permit chainsaws to be used on their land. This is in marked contrast to the woodland workers termed by Collins (2004) as "the new tradition" who have taken this livelihood option after other careers. These tend to be vocal, experienced communicators, with no reservations in making their views known. This is likely to be at the root of the conclusions reached by previous researchers that the chestnut sector had virtually died out. An exacerbating issue is that changes in rural land ownership have resulted in negativity towards tree felling, so coppicing within woods, rather than in more visible areas, has exacerbated the tendency for it to pass un-noticed. Incentives, in the form of subsidised training, free signs (reassuring the public that coppicing is beneficial, rather than harmful, to wildlife) and the authors reputation for homemade cake has played an important role in engaging with the coppice workers and generating data. 


\section{Results and discussion}

This investigation was conducted using a mixed methods approach. The results will therefore be discussed in relation to the research questions.

\section{The extent of active coppice management}

This is not a systematic survey but depends on workers, and some woodland owners and managers estimating areas. However the verification carried out on about $10 \%$ of returns demonstrated a high degree of accuracy, perhaps not surprising as the majority of returns were from those whose livelihood depended on woodland. This survey, first carried out in 1999, and now in the $11^{\text {th }}$ year, has variable numbers of responses and gives fluctuating areas. As an example in 2007/2008 the figure of 274.9 ha, was virtually the same as that of 250 ha for 2008/2009. However in the former 202 ha was mixed species, in the latter 193 ha was chestnut (Bartlett 2011a). This was never intended to provide accurate information but rather as a barometer of trends and, secondarily, as an engagement tool. It does provide clear evidence that far more coppice was - and is - being harvested than previously thought. The majority of the records for chestnut are from Kent, Surrey and the Sussexes; most for hazel coppice is to the west, Hampshire and beyond, and areas for this species are small.

\section{The coppice workforce}

Face to face questionnaires were completed with 204 coppice workers active in South East. Eighteen were classified as new entrants to the profession, having been working for less than three years, and were not included in this analysis as many do not persist and the intention was to survey established workers. Of the remaining 186 individuals 11 were female and more than $50 \%$ were based in the county of Kent (Tab. 1). In total 178 , or almost $98 \%$, were active in the four adjoining counties of Kent, Surrey, East and West Sussex; this most easterly tip of southern England was historically and arguably remains the heart of the coppice industry.

This part of England has relatively high woodland cover and is where most of the chestnut is found. When asked to identify tree species coppiced 46 declared they cut nothing but chestnut, 9 only hazel (Corylus avellana) while the majority cut a mixture (Tab. 2). Those that did not fell material were working full time as chestnut processors, provided with raw material by others.

Further questioning revealed a family tradition of working in coppice, particularly with chestnut. Forty-six gave the main reason for joining the industry as joining family and a total of 80 were working with family members; 6 of these were female. The majority were found to be self-employed (133). Historically woodland work took place in the winter months, with some processing during the summer, as it was combined with agricultural work, the seasons fitting well together (Rackham 1986). With the modernisation of agriculture in the latter half of the $20^{\text {th }}$ century summer work on farms reduced and most respondents (161) now work in coppice throughout the year. This is potentially in conflict with nature conservation objectives and this is likely to be why 6 declined to provide information on this aspect. The 16 who worked in coppice only part of the year all did so in winter. A more complex picture emerged on further probing with 89 declaring that they were totally dependent on coppicing/processing for their livelihoods; the inference being the others were engaged in other activities. However this may be misleading as some responded with respect to household, rather than individual, income so this requires further investigation before any conclusion can be drawn.

The largest number (126) produced firewood, in the form of domestic logs with 111 producing fencing material; more than half of these were in Kent. Minor products included charcoal (37), hurdles (21), rustic
Tab. 1 - Location of coppice workers based on home address.

\begin{tabular}{lrr}
\hline County & $\mathrm{N}$ & \multicolumn{1}{c}{$\%$} \\
\hline Dorset & 2 & 1.5 \\
East Sussex & 39 & 23.1 \\
Hants & 9 & 4.8 \\
Kent & 102 & 54.8 \\
London & 2 & 1.5 \\
Surrey & 16 & 8.6 \\
West Sussex & 21 & 11.3 \\
No reply & 1 & - \\
\hline
\end{tabular}

trellis (20), chip (10) and thatching spars (10). The most important, highest value, product is fencing - which includes hurdles and trellis - with some of the firewood and the chip being a by-product. However it should not be assumed that chip is for fuel as, in at least three cases, this was chestnut by-product sold as mulch for playgrounds. The questionnaire ended by asking respondents how they felt about their businesses. Seventy-eight felt it was improving, 79 that it was steady with just 9 reporting a decline. Twenty did not respond. Some $94 \%$ identified word of mouth as the principal

Tab. 2 - Age of workers and main species worked.

\begin{tabular}{lrcccc}
\hline Age & Total & $\begin{array}{c}\text { Chestnut } \\
\text { only }\end{array}$ & $\begin{array}{c}\text { Hazel } \\
\text { only }\end{array}$ & $\begin{array}{c}\text { Mixed } \\
\text { species }\end{array}$ & No cut \\
\hline$<20$ & 3 & 0 & 0 & 2 & 1 \\
$20-29$ & 30 & 6 & 0 & 21 & 3 \\
$0-39$ & 31 & 9 & 2 & 18 & 2 \\
$40-49$ & 62 & 13 & 2 & 44 & 3 \\
$50-59$ & 29 & 10 & 1 & 16 & 2 \\
$60-69$ & 19 & 5 & 4 & 8 & 2 \\
$>70$ & 6 & 0 & 0 & 3 & 3 \\
No age given & 6 & 3 & 0 & 1 & 2 \\
Totals & 186 & 46 & 9 & 113 & 18 \\
\hline
\end{tabular}

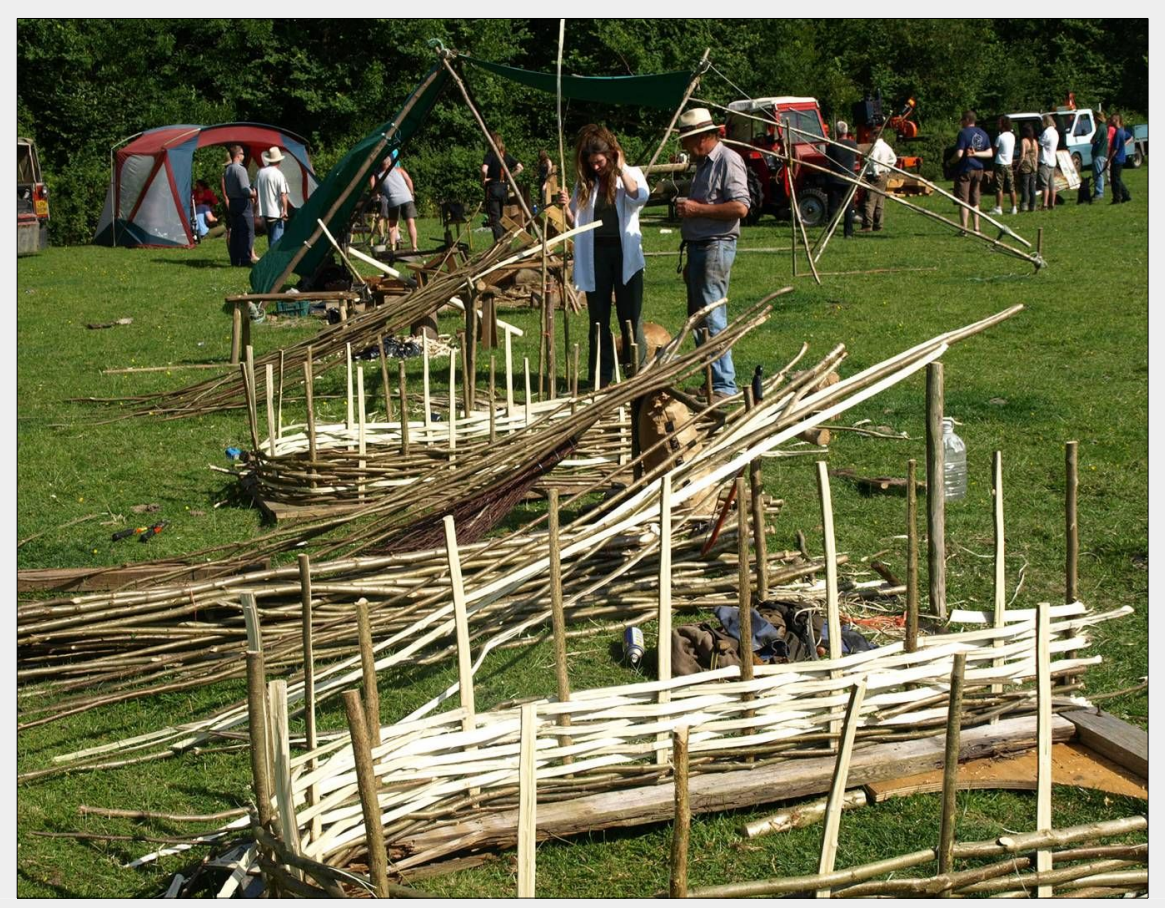

Fig. 2 - Hazel coppice workers. 
Fig. 3 - Chestnut fencing: pale bundles.

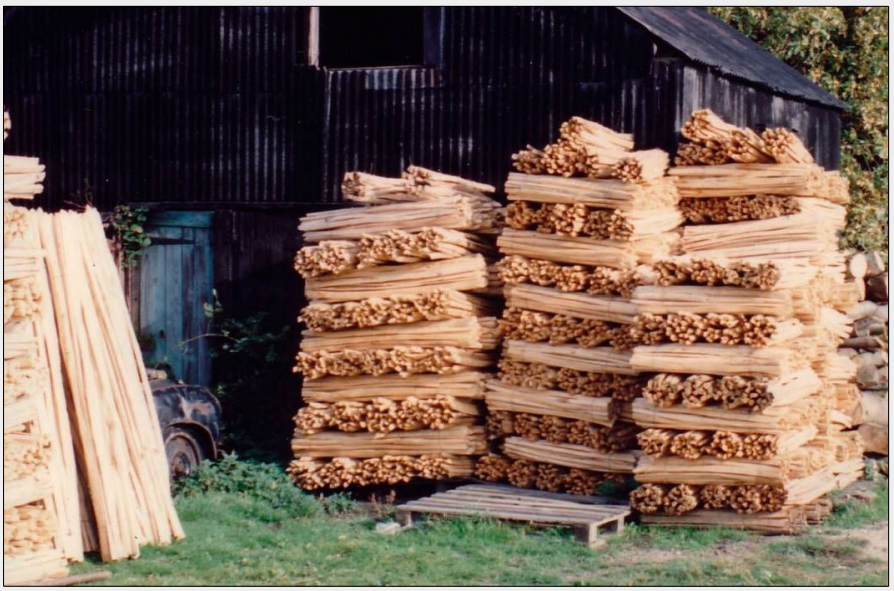

method of selling their products and for 74 of these it was the sole marketing method; very few used the internet.

\section{Distinctions between different coppice sectors}

This research confirmed previous studies (Bartlett \& Rossney 2007, Bartlett 2011a, Bartlett 2011b, Bartlett 2011c) that identified three distinct sectors in the coppice industry in South East England, the only region with significant activity. These are based on harvesting mixed broadleaves species, hazel and chestnut respectively with the differences explained in the following sections.

Mixed species have long been the source of fuelwood with all the by-products of value added processing, down to small twigs bundled into faggots, being saleable. The domestic log market is significant (but has not been quantified) and mostly conducted on a part time, casual, seasonal basis using mixed species, and is ad hoc rather than efficiently organised. Logs are often delivered from pickup trucks or even more profitable - sold in small net bags on garage forecourts. Despite incentives for machinery (harvesters and chippers) and burner installation felling coppice for chip and pellets generates very low returns; it is more viable for woodland owners to produce for their own use. Workers in this group may also be tree surgeons in the summer and most would not identify with the term "coppice worker", although some in the more specialist groups do produce firewood as a by-product of their value added processing.

Hazel (Corylus avellana) grows fast and was traditionally harvested at 5 to 8 years growth. At this age it is still flexible and was used to weave hurdles used as mobile sheep fencing prior to the introduction of wire and changes to husbandry, with sheep kept in fields rather than ranging with a shepherd and folded together at night. Hazel coppicing is undergoing a revival with woven structures being used in gardens, as illustrated in Fig. 2, charcoal burning, which utilises older wood, and small scale craft products.

There is no direct link to tradition and many of the hazel coppice workers come from quite different, not necessarily rural, backgrounds. Many were found to have made a life style choice, leaving more lucrative (but perhaps more stressful) employment for work in the woods. They have usually attended short training courses, work individually or as couples, and sell direct to their customers, often at farmer's

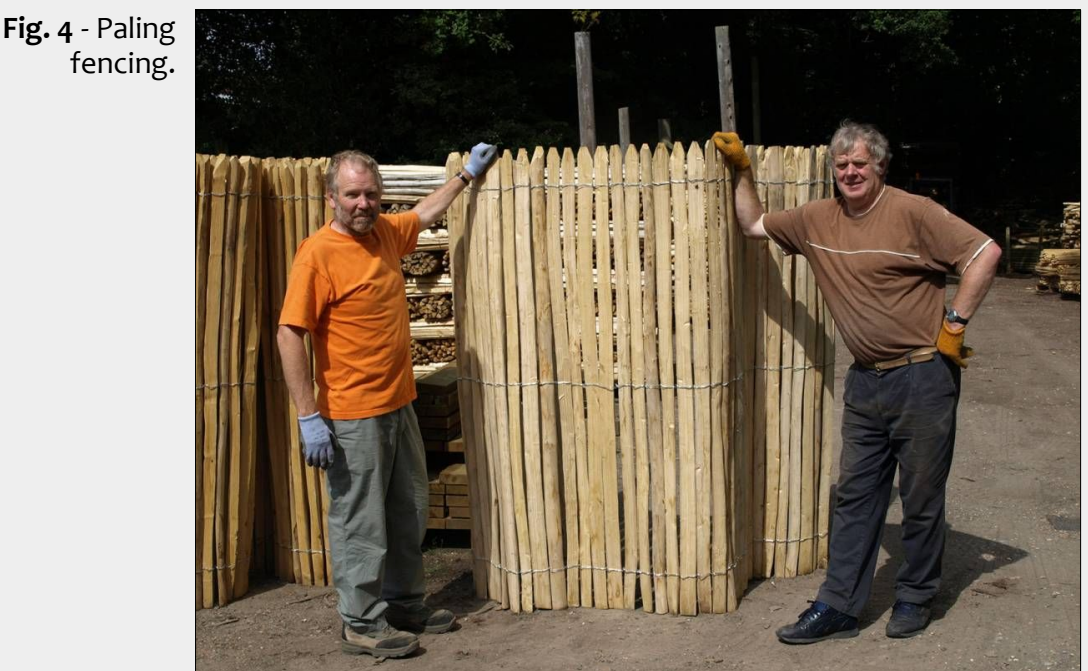

markets or at craft fairs, gaining additional income by demonstrating.

The third group specialise in harvesting and/or processing chestnut (Castanea sativa) which is found predominantly in the south east (Garratt 2009). This is harvested on rotations between 3 to $40+$ years with the principal product being cleft fencing, from small trellis and pales (Fig. 3, Fig. 4) to larger posts and rails. It is a very durable wood that cleaves (or splits) easily and this has all the characteristics of a genuinely traditional industry still featuring family groups with new entrants learning directly from older workers; many have started by helping out as children.

Although most are self-employed there is a high level of co-operation with individuals working together as and when required. These sell their produce, which may be cut and sawn to length, or processed in the wood, to "merchants" who negotiate sales, may have a team of specialist processors cleaving in their yard, and may buy standing wood and identify cutters for it. Harvesting takes place all year, with additional workers in winter. The chestnut coppice sector is the only one that can be considered as of industrial scale, with the area cut orders of magnitude greater than for hazel. There is a significant export market in addition to sales throughout the UK, and this appears to be growing.

Few women were identified in any of these three groups, although it is known that many workers rely on female partners or family members for assistance with paperwork.

\section{Issues affecting and potentially limiting} coppice management

There are no government restrictions or permissions required for most coppice harvesting in England, the exception being some of the very large chestnut cut for rails which requires a Felling License. Some landowners impose their own restrictions, often linked to use of the wood for shooting and there is strict legislation requiring a risk assessment approach for all woods where European Protected Species such as dormice (Muscardinus avellanarius), bats (Chiroptera) or breeding birds are present.

The focus groups were held to identify specific issues affecting the workers with the intention of feeding this information to decision makers and to inform proposals for development. Participants, representing forty six businesses, included all three sectors, although either chestnut or hazel workers predominated at each event. There is little mixing between these and the tree species are found in different localities. There are specific issues, such as deer browsing hazel but not chestnut (Bartlett 2011b), however, the aim was to gain a general overall view. The facilitated peer group discussions, in a non-threatening environment, resulted in participants identifying the strengths, weaknesses, opportunities and threats to their busi- 
Tab. 3 - Top five results from the SWOT exercise.

\begin{tabular}{|c|c|}
\hline Strengths & Opportunities \\
\hline $\begin{array}{l}\text { Product quality } \\
\text { Available wood; raw material } \\
\text { Good at job; experience knowledge skill; quality of work; flexible } \\
\text { Sustainably managing woods; low environmental impact; good for } \\
\text { the environment } \\
\text { Demand for products; good customer base; reliable market }\end{array}$ & $\begin{array}{l}\text { Increasing markets; Large potential market; } \\
\text { Growing firewood markets } \\
\text { Education/training; plenty of wood; range products; environmental } \\
\text { concern; chestnut's durability as an untreated hardwood } \\
\text { Making better use of dis-guarded material; FSC certification; } \\
\text { promoting local products/ in-house marketing } \\
\text { Educating the public to demand for home grown products; being } \\
\text { positive rather than not negative }\end{array}$ \\
\hline Weaknesses & Threats \\
\hline $\begin{array}{l}\text { Old machinery and equipment } \\
\text { Marketing } \\
\text { Lack of capital } \\
\text { Small business/lone working } \\
\text { hard labour intensive work with impact on health; lack of training; } \\
\text { legislation \& HSE; poor product prices; lack of young pale makers } \\
\text { and cutters }\end{array}$ & $\begin{array}{l}\text { Insurance and housing costs } \\
\text { Personal health or injury } \\
\text { Competition from other workers/poor quality products/under } \\
\text { cutting prices cheap imports (this refers specifically to hurdles) } \\
\text { Lack of labour (from cutters to pale makers) } \\
\text { Legislation and bureaucracy }\end{array}$ \\
\hline
\end{tabular}

nesses. The "headline" responses in each category are given in Tab. 3. It is clear that these workers have confidence in the market and their ability to produce high quality products. There is also a high level of awareness of opportunities, such as certification and promotion of local products with environmental benefits. However the structure of the industry, with many working alone, or in small groups, challenged by lack of capital and equipment and burdened by legislation, prevents them taking collective advantage of these. The shortage of workers, chestnut pale makers as well as cutters, was identified in both the threat and weakness categories, and is thought to be related to expectations with some new entrants starting enthusiastically but finding the work hard and, particularly in harsh weather, it can be difficult to maintain when being paid according to production rather than an hourly rate.

Further discussions, involving the "coppice merchants" rather than the workers, revealed concerns about security, with vehicle and equipment thefts common, uncertain tenancy of work yards and cash flow.

\section{Conclusions}

The existence of three distinct coppice sectors has wide implications and understanding the differences between them, not merely with respect to raw material and product, but also social structure and motivation, is fundamental to any future development. Government forestry policy in England is to increase woodland management for biodiversity and recreation, to increase carbon neutral energy and for rural development, with the key message that woodlands are "good for people, good for nature and good for the economy" (DEFRA 2013). Key policy objectives for forestry are to "bring more woodland into active management to help the sector to find its voice and improve its economic performance".

This assumes that there is a baseline, and accurate data on current management, and an effective mechanism for the workforce to communicate with policy/decision makers. Neither is the case for coppice woodland management in South East England. The voluntary coppice survey is a "citizen science" approach to establishing the area of coppice cut and had provided evidence that this is significant. The assumption that promoting biomass fuel to drive coppicing is highly unlikely to succeed when the message from the workforce is that it is not a shortage of markets but rather too few workers to meet existing ones which, in addition, are more profitable than producing fuel.

The coppice survey has demonstrated that significant coppice woodland management is taking place each year in South East England. Three socio-economically distinct sectors have been identified and the marked difference, particularly between the chestnut and hazel workers, indicates that a single approach to increasing the area of woodland managed by coppicing is unlikely to succeed. The stated aim of helping the coppice sector to "find its voice" will require multiple approaches to knowledge transfer and participatory engagement.

Understanding the past has long been touted as the key to planning the future but do we really understand what a "modern" coppice industry for the future will be? Coppice woodland management is "valued" for different, potentially conflicting (ecosystem) services. In England the agencies and key stakeholders interested in, for example, nature conservation and recreation, communicate in forums such as Local Nature Partnerships, organised at county level. Woodland owners are well represented however there is no mechanism for those working in the woods, particularly in the chestnut sector, to engage in the decision making processes. The results of the coppice survey strongly suggest that more woodland is in active management than was previously thought, and the focus group and questionnaire-based research indicate a significant workforce who are not constrained by market issues. The issues they raised imply that there is a need for business and supply chain development, and further investigation into recruitment and retention of new entrants would be beneficial.

It would be interesting to explore whether this scenario, with the work force a neglected area of research, is unusual or common across Europe? Perhaps closer integration between academics and state forestry authorities for developing an understanding of the need for, and requirements of, a "modern" coppice industry would be beneficial.

\section{References}

Bannister NR (2007). The cultural heritage of woodlands in the south east with reference to the High Weald, Kent Downs and Surrey Hills areas of outstanding natural beauty. Forestry Commission, Bristol, UK, pp. 89. [online] URL: http://www.forestry.gov.uk/forestry/infd-7dlcji Bannister NR, Bartlett DMF, Jennings T (2005). Exploring your woodlands history. A guide for community groups and woodland owners. Canterbury Woodlands Research Group, Local Heritage Initiative, Kent, UK, pp. 23. [online] URL: http://www.forestry.gov.uk/pdf/exploring_your woodlands history.pdf

Bartlett DMF, Rossney D (2007). Socio-economic analysis of the coppice industry in south east England. Quarterly Journal of Forestry 101 (4): 285-290.

Bartlett DMF (2011a). The history of coppicing in south east England in the modern period with special reference to the chestnut industry of Kent and Sussex. PhD thesis, University of Greenwich, UK, pp. 263.

Bartlett DMF (2011b). Identifying issues for the coppice industry. Quarterly Journal of Forestry 105 (2): 131- 133.

Bartlett DMF (2011c). In pursuit of the truth about coppice woodland management in the south east. Practice 73: 20-21.

Betts A, Claridge J (1994). New markets for old woods. Conference Report. The Forestry Au- 
thority for England HMSO, London, UK, pp. 155. Bonney R, Cooper CB, Dickinson J, Kelling S, Phillips T, Rosenberg KV, Shirk J (2009). Citizen science: a developing tool for expanding science knowledge and scientific literacy. BioScience 59 (11): 977-984. - doi: 10.1525/bio.2009. 59.11.9

Collins EJT (2004). Crafts in the English countryside: towards a future. Countryside Agency Publications, Yorkshore, UK, pp. 324.

DEFRA (2013). Government Forestry and Woodlands Policy Statement Incorporating the Government's Response to the Independent Panel on Forestry's Final Report. Department for Environment, Food \& Rural Affairs, London, UK, pp. 49. [online] URL: https://www.gov. uk/government/publications/government-fores try-policy-statement

Edlin HL (1973). Woodland crafts in Britain ( $2^{\text {nd }}$ edn). Country Book Club, Newton Abbot, UK, pp. 182.

FitzRandolph HE, Hay MD (1926). The rural industries of England and Wales vol. 1: timber and underwood industries and some village workshops. Clarendon Press, Oxford, UK, pp. 239.

Forestry Commission (2004). Seeing the woods for the trees: a forestry and woodlands framework for the South East. HMSO, UK, pp. 64.

Forestry Commission (2006). A woodfuel strategy for England. Forestry Commission England, Bristol, UK, pp. 28. [online] URL: http://www. forestry.gov.uk/pdf/fce-woodfuel-strategy.pdf/ \$FILE/fce-woodfuel-strategy.pdf

Forestry Commission (1985). Guidelines for the management of broadleaved woodland. Policy Note no. 5, Forestry Commission Scotland, HMSO, Edinburgh, UK.
Geraint Jenkins J (1965). Traditional country craftsmen. Routledge, Abingdon, Oxon, UK, pp. 251.

Garratt L (2009). British and Irish hardwoods trust. Report no. 523392, Chestnut Project 2009, Department of Energy and Climate Change, London, UK.

Rackham O (1986). The history of the countryside. JM Dent and Sons, London, UK, pp. 400.

Rackham O (2003). Ancient woodland: its history, vegetation and uses in England. Castlepoint Press, UK, pp. 624.

Silverton J (2009). A new dawn for citizen science. Trends in Ecology and Evolution 24 (9): 467-471. - doi: 10.1016/j.tree.2009.03.017

Warren M, Clarke S, Currie F (2001). The coppice for butterflies challenge: a targeted grant scheme for threatened species. British Wildlife 13 (1): 21-28. 